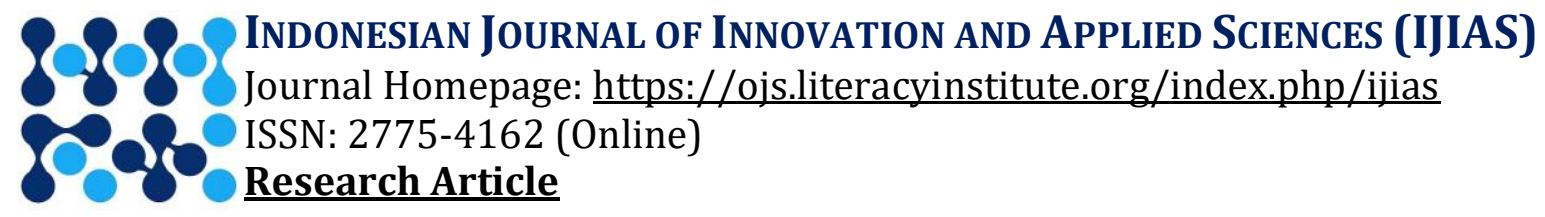

\begin{tabular}{l|l|l|l|l}
\hline Volume 1 & Issue 2 & June (2021) & DOI: 10.47540/ijias.v1i2.197 & Page: $95-104$ \\
\hline
\end{tabular}

\title{
Digital Technologies on Mathematics Education at the Covid-19 Lockdown Situation in India
}

\author{
Kaushik Das \\ Department of Mathematics, Gobardanga Hindu College, India \\ Corresponding Author: Kaushik Das; Email: kaushik.das53@gmail.com
}

\begin{tabular}{ll}
\hline A R T I C L E I N F O & A B S T R A C T \\
$\begin{array}{l}\text { Keywords: Covid-19 Pandemic, Digital } \\
\text { Technologies, E-Learning, Lockdown }\end{array}$ & $\begin{array}{l}\text { This paper introduces digital technologies and mathematics education at the Covid- } \\
\text { 19 Lockdown situation in India. The researcher focused on ICT-based tools or } \\
\text { techniques for supporting innovative teaching and learning processes in } \\
\text { mathematics and the study of these processes including the support that has to be } \\
\text { given to teachers and educators. Researchers involved in mathematics education }\end{array}$ \\
$\begin{array}{l}\text { Received : 15 March 2021 } \\
\text { Revised }: 26 \text { May 2021 } \\
\text { Accepted }: 05 \text { June 2021 }\end{array}$ & $\begin{array}{l}\text { fragmentation of the field. ICT-based technologies are likewise going to be the } \\
\text { extraordinary friend in need of the socio-economic in rural India. The data were } \\
\text { analyzed using both descriptive and as well as inferential statistics and the } \\
\text { methodology of the study is a mixed type involving interpretative, analytical study } \\
\text { of documents, survey questionnaire and study both primary \& secondary sources, } \\
\text { like books, university news, expert opinion, articles, journals, thesis, and websites, } \\
\text { etc. Finally, meaningful suggestions are offered. }\end{array}$ \\
\hline
\end{tabular}

\section{INTRODUCTION}

The entire world is confronting the greatest emergency which has come about in absolute lockdown in India and as well as in other countries. Indian instruction framework is seriously influenced and confronting urgent time. All the schools and universities were shut and all the inward assessments, what's more, semester assessments were deferred due to Covid-19. Conclusion of schools, schools, and colleges has brought numerous challenges in training framework like a break in the learning of understudies, direct of assessment and inside appraisal, enlistment of encouraging resources and affirmation process in the coming meeting and so forth. The Government of India requested an across-the-country lockdown on the 24th of March 2020 as India was on the rundown of nations influenced with Covid-19 around the world.

The Covid-19 influenced circumstances to remain at now 10, 80,194 cases are confirmed, 3, 74,243 cases are active6, 78,709 cases are recovered and 26,842 cases are deceased in the early afternoon of 19th July 2020 in India. 1, 37, 91,869 are tested in India as of 19 July, 5:15 PM IST 2020. Mathematics is the father of all Sciences. Mathematics is envisioned as the vehicle to prepare a youngster to think, reason, examinations and express intelligently, associative to any subject including investigation and thinking. Science assists with instilling the aptitudes of measurement of encounters around the students who thusly do explore different avenues regarding numbers and types of Geometry, outline speculations and check them, sum up the discoveries with evidence, settle on choices applying Mathematics, create accuracy, objective and expository reasoning, thinking, fitness to take care of issues, uplifting perspectives and tasteful sense. Mathematics is the basis of the Science and Technical Education Pyramid, on which the entire structure of progress of advancement depends. Mathematics is the establishment stone of the huge superstructure of Science and Technical instruction, which has the necessity for our monetary turn of events, modernization of the social structure, and powerful working of the popularity-based organization. 
Learning and conversation technologies (ICT) are a basic piece of day-by-day life, including the teaching-learning process (Das, 2021a). Learning and conversation technologies (ICT) are a basic piece of day-by-day life, including the teachinglearning process (Das, 2019a). Right now, there is a deficiency of exploration that led to the utilization of computerized stages for learning science. Be that as it may, one such ongoing report shows, that understudies learn mathematics better with successful and proper innovation, while another past investigation features that the reception of innovation in science instruction improves learning. It isn't yet known precisely what sort of advanced mechanical devices that arithmetic understudies may use during the Covid-19 conclusion period. As they will be required to adapt remotely in their homes. It is against this hole of information that this investigation wishes to smaller.

Many State Governments of India are likewise investigating the internet learning stage for getting Table. 1. Lockdown Cycle by the India Government to online instructive assets, during the progressing lockdown. They are hoping to structure approaches to assist understudies with continuing with their getting the hang of during the across-the-nation lockdown due to Covid-19. The point is to successfully proceed with the scholarly patterns of the understudies and not let the lockdown influence their learning. They are getting ready for understudies to give sound and video-based substance alongside self-assessment works out.

The Government of India ordered a nationwide lockdown on the 24th of March 2020 as India was on the list of countries affected with COVID-19 worldwide. As expressed by the clinical specialists, and experienced by us the lockdown is the best answer to maintain a strategic distance from the widespread infection among the individual. In India, on the accompanying time frames, across the nation lockdown circumstance was executed. Likewise to battle this scourge, one day "Janata Curfiu" was watched on 22-03-2020.

\begin{tabular}{|c|c|c|}
\hline Lockdown Cycle & Duration & days \\
\hline Lockdown 1 & $25-03-2020$ to $14-04-2020$ & 21 days \\
\hline Lockdown 2 & $15-04-2020$ to $03-05-2020$ & 19 days \\
\hline Lockdown 3 & $04-05-2020$ to $17-05-2020$ & 14 days \\
\hline Lockdown 4 & $18-05-2020$ to $31-05-2020$ & 14 days \\
\hline Lockdown 5 & $01-06-2020$ to $30-06-2020$ & 30 days \\
\hline
\end{tabular}

The consideration of innovation like e-learning applications, digital books, online practice tests, enotes, and so forth, will assist with improving the instruction framework. A large number of uses are accessible for the understudies to adapt carefully. The government is including such ICT devices like savvy sheets, visual/sound types of gear, programming for school/school executives. The eLearning establishment with the assistance of the World Wide Web (WWW) using the Internet attempted its best prospects to advance separation instruction, virtual and e-Learning approach by conveying and sharing assets, advancing dynamic eLearning advances. The development of distributed computing innovation has exceptionally affected the Online Education Market in India. The cloud innovation with its potential abilities gives a huge measure of information, data, and substance at single stages to e-Learning Organizations in India.

Data and Communication Technology (ICT) in the field of instruction is a huge idea to comprehend. The different curricular formative ventures have been completed with the help of IITs and NITs. The National Mission on Education activity by the Government of India is relied upon to support the Gross Enrolment Ratio (GER) in Higher Education by 5 rates (\%) focuses during the Eleven Five Year Plan (2007-12).

To help 'Work from home' culture for the scholastic errand of the staff/understudy and to make best and beneficial utilization of lockdown testing period, UGC coursed a letter dated 25/03/2020 for utilization of 10 ICT activities of MHRD/UGC to guarantee continuous instructing and learning exercises for the scholarly club viz. Swayam online courses, UG/PG MOOCs, e-PG Pathshala, e-content courseware in UG subjects, Swayamprabha, CEC-UGC YouTube channel, National Digital Library, Shodhganga, E-Shodh Sindhu and Vidwan, and so on. Again the ASC/ HRDC of various colleges sorts out online FDP, workshops as online courses with standard 
direction/supplemental class. Aside from the above recorded online data sources, the DIKSHA ELearning Platform/Diksha Mobile App., EBalbharati/Ebalbharati App., NROER (National Repository of Open Instructive Resources) and Global Digital Library and so on such ICT devices additionally bolster 'gaining from home' perception.

The rising information has drawn from both the fields of mathematics education and digital technologies in education. The education sector in Spain has been experiencing a few changes and arithmetic training has not been forgotten about. Specifically, the latest strategy recommendations have included as a key point the comprehensiveness of ICTs in science going to hence fulfilling a need normal for our present computerized time. In the most recent decades, the advancement of microworlds and instructive including them has in this manner been upheld by constructivist draws near however it has additionally added to their dynamic development (Papert, 1980; Kafai \& Resnick, 1996). It is essential to understand that in these new mechanical directions instructors do at present make a difference, however, what is unexpected, is that there is no agreement about a dependable or target method of distinguishing great educators. Numerous examinations in the field of ICT in instruction have indicated that perspectives towards ICTs impact instructors' acknowledgment of the helpfulness of ICTs in the exercises, and impact whether educators coordinate ICTs into their study halls or not (Clark, 2001; Huang \&Liaw, 2005).

It is having confidence in the science instruction network that fitting a combination of ICT will affect each part of arithmetic training: what sort of science is to be introduced and how science is educated and learned (Leung, 2013). Viable utilization of ICT in arithmetic instruction could prompt a more student-focused showing practice since the incorporation of ICT on a very basic level changes the instructor understudy association and the manners in which science content is being introduced to understudies (Ertmer, 2005; Gillen et al, 2007; Pierce \& Ball, 2009). These progressions have been ordinarily accepted to have constructive outcomes on arithmetic instructing and learning. Although ICT is accepted to have positive advantages on science training, as a general rule, now and again instructors don't utilize
ICT at all or use it in a customary manner, such as utilizing ICT to continue directly educating (Ertmer, 2005; Goos \& Bennson, 2008).

All the more critically, the successful mix of ICT can make arithmetic (e.g., unique ideas) progressively available to understudies and further encourage understudies' comprehension of science ideas, build up understudies' critical thinking aptitudes, improve understudies' more elevated levels of scientific reasoning, and even, for the most part, improve understudies' math accomplishment (Bennson, 2008; Li \& Ma, 2010). Educators' perspectives toward ICT were a lot more noteworthy marker of their expectation of the utilization of innovation than their convictions, such as self-viability convictions. By and large progressively positive mentalities towards ICT will support higher homeroom ICT coordination while negative perspectives dishearten its utilization. In arithmetic training, it was discovered that it is just when instructors accept that the utilization of ICT will upgrade understudies' science learning or increment understudies' inspiration, pleasure and certainty contrasted and different methodologies that they will consider to utilize innovation (Hennessy, 2005; Pierce \& Ball, 2009).

If instructors accept that to show comprehension of arithmetic, an understudy must have the option to take care of issues without the help of ICT or even accept that the utilization of ICT will upset the improvement of understudies' capacity, for example, the capacity of figuring, they won't incorporate ICT in science training, or use it in a customary information transmission way (Goos \& Bennson, 2008; Pierce \& Ball, 2009). Laptop computers address the needs of software and networking but there are fewer pro levels that help maintain a more balanced classroom environment \& the mathematics laboratory classroom solves this problem (Das, 2019b).

The nearness of data innovation has carried changes to understudies' learning examples and styles. The advancement of innovation likewise expects colleges to create separation instruction or what is called e-realizing. E-learning is relied upon to be an answer to investigate more extensive abilities and information that should be possible whenever and anyplace utilizing PC or cell phones. The advancement of innovation likewise expects colleges to create separation instruction or what is 
called e-realizing. E-learning is required to be an answer to investigate more extensive aptitudes and information that should be possible whenever and anyplace utilizing a PC or cell phone (Iqbal, Javed, and Ahmad, 2010). Technological advancements are expanding quickly in human life. The Internet has changed individuals' ways of life, either from social, instructive, well-being, and even government (Rochmadi et al, 2017).

Like any other language, so also mathematics exercises a symbolic power \& Mathematics makes part of a range of technological actions. Also, it's an ingredient of our techno-nature. Computerized learning couldn't supplant customary educating, it could accomplish the best showing impact and have students be happy to learn by strengthening conventional instructing with advanced learning and extensively rehearsing the two techniques in educating action (Yien et al, 2011) called attention to the contrast between advanced learning and customary instruction in learning conditions and people. Customary instructing, with "address" in study halls, was the most conventional and delegate educating strategy. To put it plainly, it alluded to educators conveying showing materials in the instructing movement to students through understanding. With its long history, it has been extensively applied is as yet one of the positive showing techniques for teachers. Mathematics phobia is also a barrier to teaching-learning mathematics and it's correlated with mathematical problems, formulae, and curriculum (Das \& Gupta, 2020). In any case, the educational program plan and the creation of encouraging materials for advanced learning were a computerized substance that students could unreservedly choose various courses and showing materials, as indicated by the level and inclination, to accomplish the customfitted learning result (Sun et al, 2012). There is a considerable application of mathematics in various disciplines like history, geography, fine arts, and physical education (Das, K. et al, 2019).

With the developing accessibility and transmission capacity of the web, analysts got keen on the capability of online intelligent applications or applets for mathematics instruction. The upsides of online substances incorporate access without neighborhood programming establishment, simplicity of dispersion and refreshing for engineers, and permanent accessibility for clients as long as the web is available (Das \& Das, 2020).

Examination of the utilization of versatile innovation in science instruction is in its beginning phases however its significance is quickly developing. It is obvious that versatile innovation and PDAs specifically are extremely well known among understudies and increasingly more widespread. Remote Internet gets to takes into consideration the utilization of portable applications (additionally called MIDlets, Mobile Information Device applications), SMS and email administrations offer correspondence and coordinated effort openings, GPS offices take into consideration topographical and geometrical exercises and the device's versatile and handheld singe acteristics welcome out-of-school exercises, for instance, the social event of genuine information that illuminate science or science exercises (Daher, 2010).

While playing the game, understudies take a gander at the guide to envision where they need to make a shape, stroll to the area for the primary vertex to enter this area in the cell phone, which creates a spot on the guide, stroll to the area of the second vertex of their envisioned shape which gives a line on the screen interfacing the principal vertex with the current (moving) area, and so on. MobileMath adds a geometrical measurement to the world, changing it into a game board. MobileMath additionally welcomes scientific movement, for example, the revelation and utilization of attributes of squares, square shapes, and parallelograms, and paying heed to geometrical parts of the world. By the structure of Realistic Mathematics Education, reasonable implies that difficult circumstances introduced in learning exercises ought to be 'experientially' genuine to understudies and have meaningful, credible issue circumstances as beginning stages, so understudies experience the game's movement as appearing well and good. So did the advanced innovation 'work' for this situation? Most definitely, the appropriate response is yes.

The objectives of the study are to: (1) To find the various online tools/platforms adopted by educational institutions during the pandemic Covid19 period; (2) To find out the role of the India Government to support the online learning process during the lockdown period for Covid-19; (3) To 
study ascertain the relationship between online teaching performance and mathematics educational process in technology-rich learning environments; (4) To study the traditional teaching and digital learning on mathematics education; (5) Examine the views of learners and educators about the online learning system and uses of ICT in mathematics education.

\section{METHODS}

Method of the Study: This study is a Descriptive kind in nature. The researcher utilized both primary and secondary techniques for information assortment for his research work. These secondary study sources similar to books, articles, diaries, proposals, college news, master sentiment, official records, archives, Govt. Gazetteers, Manuals and sites, and so on. Thinking about the idea of the current issue, the researcher has chosen the Descriptive kind overview technique as the most reasonable strategy for directing the current investigation. Subsequently, normally, the specialist has utilized the various apparatuses, measurable tests, procedures, systems. The researcher collected data from survey questionnaires administered to students and faculty, interviews of senior faculty and department chairs, and document analysis of plans and policy documents.

The researcher has taken only 400 respondents by using Google Forms. The Stratified Random sampling technique has been used in the selection of the sample for the present study. The researcher makes a Google form questionnaire and collected data randomly.

\section{RESULTS AND DISCUSSION}

Now 10, 80,194 cases are confirmed, 3, 74,243 cases are active, 6, 78,709 cases are recovered and 26,842 cases are deceased on the early afternoon of 19th July 2020 in India. 1, 37, 91,869 are tested in India as of 19 July, 5:15 PM IST 2020.

Table 2. Present status of Covid-19 at India on 19 Jul, 5:15 PM IST 2020.

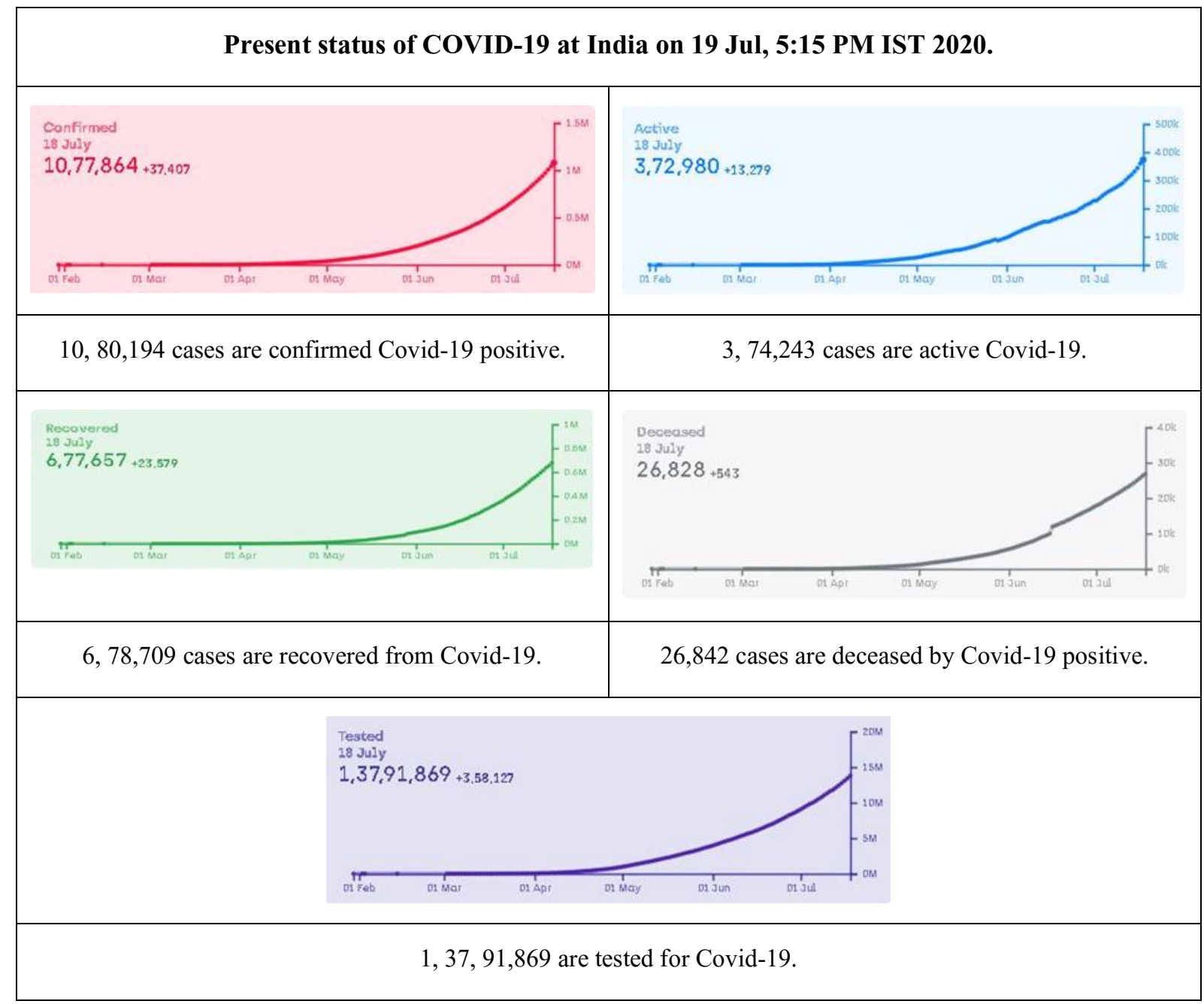


In this study researcher collected 400 responses from google forms. There are 197 are male and 203 are female respondents out of 400. Table 3. No. of male \& female Respondents.
Distribution of the respondents concerning their Gender.

\begin{tabular}{|c|c|c|}
\hline Gender & No. of Respondents. & Percentage. \\
\hline Male & 197 & $49.25 \%$ \\
\hline Female & 203 & $50.75 \%$ \\
\hline Total & 400 & $100 \%$ \\
\hline
\end{tabular}

Table 4. Respondents' opinion of the present status on the Mathematics Education at Covid-19 Lockdown Pandemic situation.

\section{Participants responds of the} present status on the

Mathematics Education at Covid-19 Lockdown

Pandemic situation.
Respondents' opinions were recorded by the Likert's five-point scale i.e. Strongly Agree (S.A), Agree (A), Neutral (N), Disagree (D), and Strongly Disagree (S.D).

\begin{tabular}{|c|c|c|c|c|c|c|c|c|c|c|c|}
\hline & & \multicolumn{2}{|c|}{ 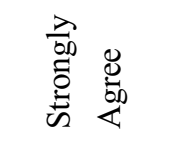 } & \multicolumn{2}{|c|}{$\begin{array}{l}\stackrel{8}{0} \\
\dot{5} \\
<\end{array}$} & \multicolumn{2}{|c|}{$\begin{array}{l}\overline{\widetilde{J}} \\
\overline{\overline{0}} \\
\bar{z}\end{array}$} & \multicolumn{2}{|c|}{ 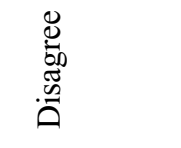 } & \multicolumn{2}{|c|}{ 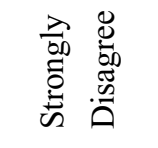 } \\
\hline & & No & $\%$ & No & $\%$ & No & $\%$ & No & $\%$ & No & $\%$ \\
\hline 1. & $\begin{array}{l}\text { Teaching comfortability by } \\
\text { using ICT to teach } \\
\text { mathematics. }\end{array}$ & 166 & 41.5 & 167 & 41.8 & 43 & 10.8 & 16 & 4 & 8 & 2 \\
\hline 2. & $\begin{array}{l}\text { Difference between } \\
\text { Mathematics teaching in the } \\
\text { classroom and teaching } \\
\text { through the Internet. }\end{array}$ & 220 & 55 & 149 & 37.3 & 27 & 6.8 & 4 & 1 & 0 & 0 \\
\hline 3. & $\begin{array}{l}\text { Difficult for students to } \\
\text { understand teaching through } \\
\text { internet. }\end{array}$ & 157 & 39.3 & 142 & 35.5 & 30 & 7.5 & 68 & 17 & 3 & 0.8 \\
\hline 4. & $\begin{array}{l}\text { Students are benefited on } \\
\text { their online Teaching equally. }\end{array}$ & 111 & 27.6 & 86 & 21.5 & 87 & 21.8 & 84 & 21 & 32 & 8 \\
\hline 5. & $\begin{array}{l}\text { Covid-19 lockdown situation } \\
\text { is harmful for the Education. }\end{array}$ & 195 & 48.8 & 146 & 36.5 & 40 & 10 & 15 & 3.8 & 4 & 1 \\
\hline
\end{tabular}




6. Pandemic Covid-19 is the
$\begin{aligned} & \text { barrier of Mathematics } \\ & \text { Education. }\end{aligned}$

\begin{tabular}{|c|c|c|c|c|c|c|c|c|c|c|c|}
\hline 7. & $\begin{array}{l}\text { Justified role of India } \\
\text { government on education } \\
\text { sector at COVID-19 } \\
\text { pandemic situation. }\end{array}$ & 33 & 8.3 & 119 & 29.8 & 121 & 30.3 & 38 & 9.5 & 89 & 22.3 \\
\hline \multirow[t]{3}{*}{8.} & $\begin{array}{l}\text { Lack of adequate skills of } \\
\text { teachers. }\end{array}$ & 114 & 28.5 & 157 & 39.3 & 80 & 20 & 42 & 10.5 & 7 & 1.8 \\
\hline & & \multicolumn{2}{|c|}{ Yes } & \multicolumn{3}{|c|}{ No } & \multicolumn{2}{|c|}{ Maybe } & & & \\
\hline & & No. & $\%$ & No. & $\%$ & & No. & $\%$ & & & \\
\hline 9. & $\begin{array}{l}\text { Teaching Mathematics } \\
\text { through social media. }\end{array}$ & 241 & 60.3 & 83 & 20.8 & & 76 & 19 & & & \\
\hline 10. & $\begin{array}{l}\text { Students' lack of computers, } \\
\text { laptop \& cell phone for } \\
\text { online learning. }\end{array}$ & 230 & 57.5 & 52 & 13 & & 118 & 29.5 & & & \\
\hline
\end{tabular}

In this study, the researcher collects $49.25 \%$ male \& $50.75 \%$ female respondents respectively. India has recorded 10, 80,194 confirmed coronavirus positive cases, 3, 74,243 are active Covid-19 cases, 78,709 cases are recovered and 26,842 cases are deceased on 19 July, 5:15 PM IST 2020.

From table no. - 4 , it is observed that $41.5 \%$ (166) respondents strongly agree \& 41.8\% (167) respondents agree in teaching comfortability by using ICT to teach mathematics. So it is clear that most of the respondents i.e. $83.3 \%$ are like teaching on ICT-based platforms.

The results from table no- 4,7 it is suggested that the 55\% (220) respondents strongly agree \& $37.3 \%$ (149) respondents agree respectively with the difference between Mathematics teaching in the classroom and teaching through the Internet. Analyzing the above results, it is found that most of the respondents believe that there is a difference between Mathematics teaching in the classroom and teaching through the Internet.

From table no- 4 , it is observed that $39.3 \%$ (157) \& 35.5\% (142) respondents respectively strongly agree \& agree with the difficulties of students understanding in teaching through the internet. Hence, $74.8 \%$ of respondents feel that the students' difficulties for online teaching.

From the above table no- 4 , it is obtained that the $27.6 \%$ (111) respondents strongly agree, $21.5 \%$ (87) respondents agree \& 21.8\% (84) respondents neutrally give their opinion about the "Students are benefited on their online teaching equally." So it is clear that $49.1 \%$ of respondents are suggested online teaching equally \& students benefit positively.

Analyzing the above results from table no-4, $48.8 \%$ (195) respondents strongly agree, 36.5\% (146) respondents agree that the "COVID-19 lockdown situation is harmful for the Education." So, most of the respondents like professors, students, teacher, researchers \& academians believes that Covid-19 lockdown situation is harmful for Indian Education as well as Mathematics education.

From table no- 4, it is observed that most of the respondents are feels the present lockdown situation and they believe the Pandemic COVID-19 is the barrier to Mathematics Education. From the above results, $32.8 \%$ (111) respondents strongly 
agree, 27.8\% (45) agree with "Pandemic COVID-19 is the barrier of Mathematics Education." So, this is a big loss for the development of Mathematics Education.

In the previous results from table no. 4 , there is a 50-50 opinion by the respondents about the justified role of the Indian government in the education sector. It is seen that the UGC's recommendations are very fruitful but not satisfactory for all kinds of online learning at the Covid-19 pandemic situation. There are $38.1 \%$ of respondents are satisfied \& $31.8 \%$ are not satisfied with the justified role of the Indian government in the education sector at the Covid-19 pandemic situation.

The previous results from table no -4 , it is suggested that $67.8 \%(28.5+39.3)$ respondents have to opinion their views against the Lack of adequate skills of teachers. It is a major disability for the teachers.

From table no. - 4, it is observed that most of the respondents have an opinion their views are positively like to teach Mathematics through social media. $60.3 \%$ (241) respondents agree with their teaching Mathematics through social media. So, respondents mostly like to use social media for their teaching.

It is obtained from table no. - 4 , most of the respondents believe that the maximum number of students have no computers, laptops \& cell phones for their online learning. The previous results suggest that $70.5 \%$ of respondents positively opinion about the Students' lack of computers, laptops \& cell phones for online learning. In rural India, it is very important to sufficient adequate devices for students to learn through e-learning.

\section{ConCLUSION}

Digital learning in mathematics allows students to try and study in the comfort of their homes. As long as students have the necessary digital devices, access to the internet, affordable internet costs, and an adequate supply of electricity, they can be able to obtain front seats in the mathematics virtual classroom for their study. In the Covid-19 lockdown period, digital learning in mathematics education appears to be the immediate quick positive response. It is undeniable that there is a significant difference between teaching in the classroom and teaching through the Internet.
Although students have difficulty in learning mathematics through online, they have benefited considerably. As the teaching strategies are developing in this technological era around the globe, prospective Indian educators do not wish to be left behind during the Covid-19 crisis. The lockdown situation is certainly an obstacle to the progress of education and mathematics education. Most students do not have enough necessary devices. And the need for more skills in teaching mathematics to teachers through digital is going to be felt. However, there have been considerable benefits in teaching mathematics using social media through the internet. Results have shown that the adoption of digital learning as a response to COVID-19 would animate the development of digital learning in mathematics, especially in India which has been historically impervious to the use of digital learning. The findings of this study converge with other studies.

\section{REFERENCES}

1. Clark, K. D, (2001). Urban Middle School Teachers' use of Instructional Technology. Journal of Research on Computing in Education, 33(2), pp. 178-195.

2. Daher. W, (2010). Building Mathematical Knowledge in an Authentic Mobile Phone Environment. Australasian Journal of Educational Technology, 26(1), pp. 85-104.

3. Das, K. \& Das, P. (2020). Online TeachingLearning in Higher Education during Lockdown Period of Covid-19 Pandemic in India. International Journal on Orange Technologies, vol. 2, no.6, pp. 5-10.

4. Das, K. (2020) A Study on Misconception of Using Brackets in Arithmetic Expression. Shanlax International Journal of Education, vol. 8 , no. 4, pp. 76-80.

5. Das, K. (2021a). Integrating E-Learning \& Technology in Mathematics Education. Journal of Information and Computational Science, Vol. 11, Issue 1, pp. 310-319.

6. Das, K. (2021b). Inclusive Mathematics Education in Classroom Practice. Shanlax International Journal of Arts, Science and Humanities, vol. 8, no. 3, 2021, pp. 1-5.

7. Das, K. et al., (2019). Applications of Mathematical Knowledge in History, Geography, Fine-Arts \& Physical Education 
Subjects in Two-Year B.Ed. Program: Indian context. Journal of Emerging Technology and Innovative Research, 6(6), pp. 8-15.

8. Das. K, \& Gupta. M, (2020). Action Research on Mathematics Phobia among Secondary School Students. International Journal of Indonesian Education and Teaching. Vol. 4, No. 2, pp. 239-250.

9. Das. K, (2019a). Role of ICT for better mathematics teaching. Shanlax International Journal of Education, 7(4), pp. 19-28.

10. Das. K, (2019b). Significant of mathematics laboratory activities for teaching and learning." International Journal on Integrated Education, 2(5), pp. 19-25.

11. Das. K, (2019c). Lack of Mathematical Knowledge in two-year B.Ed. Programme: Indian Context. Research Journal of Educational Sciences, 7(3), pp. 1-6.

12. Das. K, (2019d). Pedagogical approaches in mathematics: Indian perspectives and practices. International Journal of All Research Writings, 1(3), pp. 16-21.

13. Das. K, and Roy. D, (2019). Infrastructural Facility Faced by Trainee Teachers in New Two Years B.Ed. Program in West Bengal. International Journal of Research in Social Sciences, vol. 9, issue. 7, pp. 210-222.

14. Das. K., \& Chowdhury. R, (2019). Analytical study on practice teaching of B.Ed. Students in B.Ed. department, Gobardanga Hindu College, under WBSU in India. International Journal of Scientific Research and Reviews, 8(2), pp. 3882-3898.

15. Das. K., \& Roy. D, (2019). Infrastructural facility faced by trainee teachers in new two years B.Ed. Programme in West Bengal. International Journal of Research in Social Sciences, 9(7), pp. 210-222.

16. Das. K., Roy. D., \& Biswas. P, (2019). SWOT Analysis of Teacher Educators in B.Ed. Department Under West Bengal State University In West Bengal, India. Research Review International Journal of Multidisciplinary, 4(6), pp. 2455-3085.

17. Ertmer. P, (2005). Teacher Pedagogical beliefs: The final frontier in our quest for technology integration? Educational Technology Research and Development, 53(4), pp. 25-39.
18. Gillen. J., Staarman J. K., Littleton. K., Mercer. N., \& Twiner. A, (2007). A 'learning revolution'? Investigating pedagogic practice around interactive whiteboards in British primary classrooms. Learning, Media and Technology, 32(3), pp. 243-256.

19. Goos. M., \&Bennson. A, (2008). Surveying the technology landscape: Teachers' use of technology in secondary mathematics classrooms. Mathematics Education Research Journal, 20(3), pp. 102-130.

20. Hennessy, S., Ruthven, K., \& Brindley, S, (2005). Teacher perspectives on integrating ICT into subject teaching commitment, constraints, caution, and change. Journal of Curriculum Studies, 37(2), pp. 155-192.

21. Huang H. M., \&Liaw S. S, (2005). Exploring users' attitudes and intentions toward the Web as a survey tool. Computers in Human Behavior, 21(5), pp. 729-743.

22. Iqbal, Muhammad Javed, and Mumtaz Ahmad, (2010). Enhancing Quality of Education through E-Learning: The Case Study of Allama Iqbal Open University. Turkish Online Journal of Distance Education, 11(1): pp. 84-97.

23. Kafai, Y. \& Resnick, M. (Eds) (1996). Constructionism in practice. Designing, thinking and learning in a digital world. $N J$, Lawrence Earlbaum.

24. Leung, F. K. S, (2013). "Introduction to section: Technology in Mathematics Curriculum. In M. A. Clements, A. J. Bishop, C. Keitel, J. Kilpatrick, \& F. K. S. Leung (Eds.)" Third international handbook of mathematics education, New York: Springer, pp. 517-524.

25. Li, Q., \& Ma, X, (2010). A meta-analysis of the effects of computer technology on school students' mathematics learning. Educational Psychology Review, 22(3), pp. 215-243.

26. Papert. S, (1980). "Mindstorms: children, computers and powerful ideas." Harvester Press.

27. Pierce. R., \& Ball. L, (2009). Perceptions that May Affect Teachers' Intention to Use Technology in Secondary Mathematics Classes. Educational Studies in Mathematics, 71(3), pp. 299-317.

28. Rochmadi. Tri, Imam Riadi, and Yudi. Prayudi, (2017). Live Forensics for Anti-Forensics 
Analysis on Private Portable Web Browser.

International Journal of Computer

Applications, 164(8): pp. 31-37.

29. Sun J. Y., Han S. H., \& Huang. W, (2012). The roles of intrinsic motivators and extrinsic motivators in promoting e-learning in the workplace: A case from South Korea. Computers in Human Behavior, 28(3), pp. 942950.

30. Yien, J. M., Hung, C. M., Hwang, G. J., \& Lin, Y. C, (2011). A game-based learning approach to improving students' learning achievements in a nutrition course. Turkish Online Journal of Educational Technology, 10(2), pp. 1-10. 